\title{
CAN THE TRAPPING OF SHOREFACE SAND BY MUD LAYERS INDUCE COASTAL EROSION? THE EXAMPLE OF THE PARAIBA DO SUL RIVER OUTLET, NORTHERN RIO DE JANEIRO STATE
}

\author{
Dieter Muehe ${ }^{I^{*}}$, M. Sperle ${ }^{2}$, Moysés Gonsalez Tessler ${ }^{3}$ and S. R. Souza ${ }^{4}$
}

${ }^{1}$ Universidade Federal do Rio de Janeiro - Programa de Pós-Graduação em Geografia

(Cidade Universitária - Ilha do Fundão, Prédio do CCMN Bloco I sala: 20, 21941-972 Rio de Janeiro, RJ, Brasil) *e-mail: dieter.muehe@gmail.com

${ }^{2}$ Universidade do Estado do Rio de Janeiro - Faculdade de Oceanografia

(Rua São Francisco Xavier 524, S. 4018, Bloco E, 20550-013 Rio de Janeiro, RJ, Brasil) e-mail: msperle@gmail.com

\author{
${ }^{3}$ Instituto Oceanográfico da Universidade de São Paulo \\ (Praça do Oceanográfico, 191, 05508-120 São Paulo, SP, Brasil) \\ e-mail: mgtessle@usp.br \\ ${ }^{4}$ Husky Duck Ltda. \\ (Estrada Velha da Pavuna, 4522, 20761-171 Rio de Janeiro, RJ, Brasil) \\ e-mail: huskyduck@terra.com.br
}

A coastal segment of about $4 \mathrm{~km}$ length, (Fig. 1), has experienced severe coastal erosion located immediately southward from the Paraiba (ARGENTO, 1989). In consequence, tens of houses do Sul river mouth, forming the ocean beach of the have been destroyed by the erosion as well as by town of Atafona, in the north of Rio de Janeiro state foredune migration.

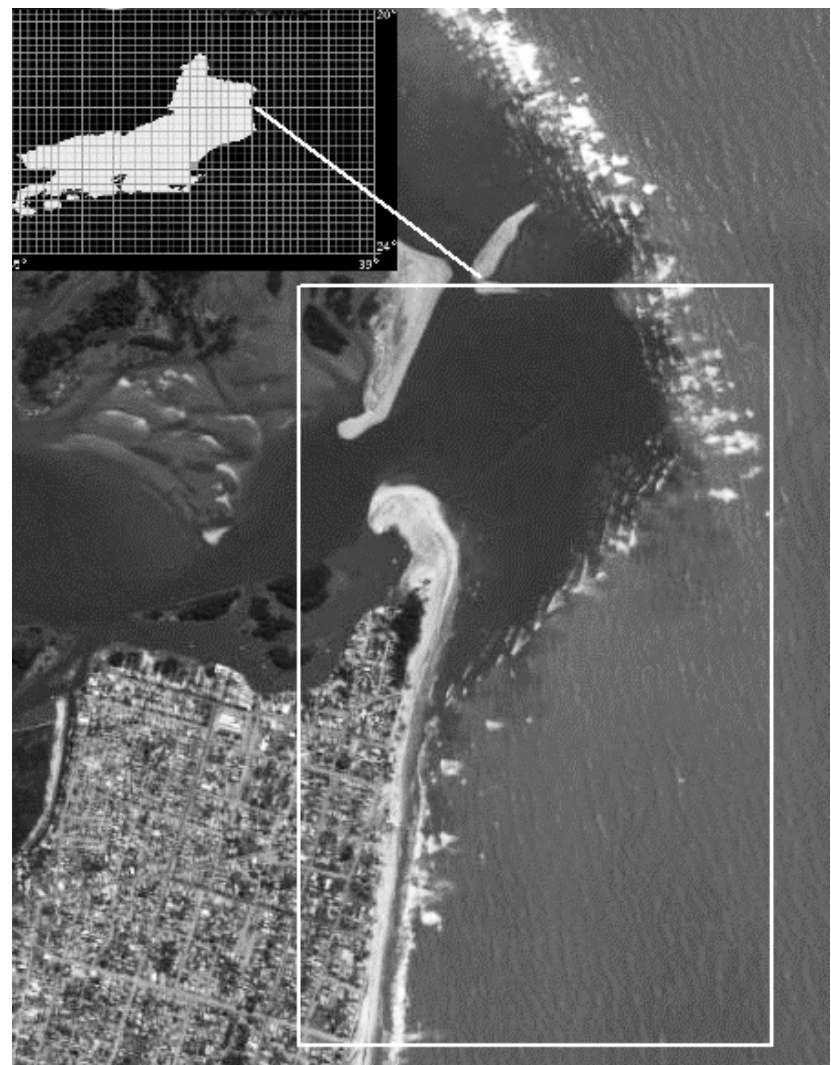

Fig. 1. Location of the area under investigation. 
Records of coastal erosion with the resulting destruction of houses go back as far as 1975 (COSTA; NEVES, 1995). Based on aerial photographs and cartographic material, RIBEIRO et al. (2004) have calculated the area of the $4 \mathrm{~km}$ long segment eroded during different periods in relation to the 2004 shoreline (Table 1).

Table 1. Eroded area in relation to the 2004 shoreline.

\begin{tabular}{ccc}
\hline \hline Period & $\begin{array}{c}\text { Erosion } \\
\left(\mathrm{m}^{2}\right)\end{array}$ & $\begin{array}{c}\text { Mean erosion rate } \\
\mathrm{m}^{2} / \mathrm{yr}\end{array}$ \\
\hline $1954-2004$ & 752,000 & 15 \\
$1964-2004$ & $1,063,000$ & 27 \\
$1974-2004$ & 410,000 & 14 \\
$1976-2004$ & 433,000 & 15 \\
\hline
\end{tabular}

Contrary to what might have been expected there had not been a continuous decrease in area from the longest to the shortest period analyzed, indicating that despite a general retrogradational trend there had also been periods of coastal accretion. Although the general trend had been correctly identified, the absolute values must be considered with caution as the mapped shoreline was the contact between the ocean and the beachface as represented in the aerial photographs used. Therefore differences due to the tide and mainly to morphodynamic variations in beach width were not taken into consideration. Variations in beach width measured monthly during one year by Fernandez et al. (2006) indicated a decrease in beach width of $60 \mathrm{~m}$ in the proximity of the river outlet and an increase of $26 \mathrm{~m}$ southward from it. The variation in area due solely to morphodynamic adjustment may, therefore, be of the order of $\pm 100,000 \mathrm{~m}^{2}$.

According to the first reports of loss of property, it seems that the process became critical after the 1970's. This is also confirmed by the findings of Bastos and Silva (2000) of a retreat rate of between $7 \mathrm{~m} / \mathrm{yr}$ and $8 \mathrm{~m} / \mathrm{yr}$ between 1989 and 1995 .

The erosion has been related to several possible causes: subsidence induced by mass movement or sediment overload (ARGENTO, 1989), reduction of river sediment and water discharge due to the construction of a dam, the construction of groins and jetties in the lower estuary, as also to the retention of sand in the lower estuary; and preferential longshore sediment transport away from the river outlet.

The decrease in river discharge due to the construction of dams, mainly for the water supply to Rio de Janeiro, as also for the generation of electricity, at the present time represents up to $70 \%$ of the
$200,000 \mathrm{~m}^{3} / \mathrm{s}$ mean monthly water discharge. Consequently, the reduction of the peak discharges affecting the delivery of coarse sediments to the shelf and to the adjoining coastline is certainly an important factor influencing the sediment budged of the beaches. According to Costa and Neves (1993, 1995) this process, together with the construction of groins and jetties in the lower estuary, has been the most important modification affecting the morphology of the estuary. Certainly this has also influenced the shape of the bottom topography of the prodelta and the direction of propagation of waves towards the coast.

An important question regarding the source of the sands for the development of the beach ridges and beaches of the front border of the coastal plain was raised by Martin et al. (1984) and Martin and Flexor (1987). According to these authors the deposition of river sand is limited to the coastal segment to the north of the river outlet while southward from the outlet the sands come mostly from the continental shelf as indicated by morphoscopic analyses of samples of quartz grains. They consequently rejected the classification of the coastal plain as a delta.

The first author of this paper had previously speculated that mud layers deposited on the shoreface and inner shelf could act as a sediment trap, thus contributing as an additional mechanism to the negative sediment budget (MUEHE, 2004). The influence of mud deposits in front of the study area has been reported by Dias et al. (1984) in the context of a discussion about the source of the sands for the progradation of the beach ridges of the coastal plain, as an argument against the shelf sediments being the main source for these deposits. Besides a map of bottom surface sediments, which extended only to the northern segment of the area under investigation, no information about the thickness of these deposits was provided. For this reason, an exploratory survey consisting of seismic reflection profiling, gravity coring and bottom sediment sampling was carried out in January 2004. The results, presented for the first time in 2004 (MUEHE, 2004; PEREIRA et al., 2006), indicated that the superficial mud layer covers a large area between the $3 \mathrm{~m}$ and $15 \mathrm{~m}$ isobaths and is from 0.5 to $1 \mathrm{~m}$ thick (Fig. 2).

While taking cores, one of the authors observed that the mud layer behaved like a plastic medium in response to the passage of surface gravity waves and not like a fluid mud which could be stirred by waves exposing the underlying sands, suggesting that it efficiently seals these sands from reworking. Geochronological analysis through ${ }^{210} \mathrm{~Pb}$ indicated a significant increase in the sediment accumulation rate from $0.45 \mathrm{~cm} /$ year - a value considered normal for coastal areas - to $1.11 \mathrm{~cm} /$ year after 1972. This increase in suspended sediment load delivered by the 
river might be the result of increased deforestation in the river basin, but can not necessarily be considered to have acted as a trigger to the coastal erosion as the mud layer existed even when the accumulation rates were lower. The occurrence of an extensive, thick mud layer, covering part of the middle and lower shoreface, an area of intense hydrodynamic activity of fundamental importance to the cross-shore transport of sediment, seems to support the hypothesis that the mud behaves as a trap to the underlying sands with the consequent increase of vulnerability to coastal erosion. As the feeding of river sands along the nearshore in the proximity of the river's outlet seems largely to be blocked by a jetty (Fig. 3), the maintenance or recovery of the beach depends fundamentally on the longshore sediment transport directed towards the river outlet by storm waves from the southeast, while that in the opposite direction will reduce the beach width, causing erosion, as a result of the action of the more frequent northeasterly waves.

In summary, we consider that the mud trap effect increases the vulnerability of the coast to erosion due to the strong dependence of the longshore sediment supply, a scenario highly dependent on the wave regime. Alongshore sediment transport rates off Atafona have been estimated by Cassar and Neves (1993) and indicated that in every season the residual transport was southerly and therefore away from the river outlet. Detailed beach profiling and sediment sampling on the shoreface of the same area, carried out by Fernandez et al. (2006), confirmed the above considerations and concluded that neither the shelf off the study area, nor the river itself, is the source of the beach sediments.

The confirmation of the potential influence of the mud layers as a significant mechanism to reduce cross shore sand exchange and consequently to increase the vulnerability to coastal erosion should be taken into consideration by any engineering solutions for the stabilization of the coastline in the study area as also in other areas with a similar trapping mechanism. This may also apply to other sediment fraction since beach profiles demonstrating instability could also be related to the deposition of finer sediments, as the original ones, in various places on the shoreface of the coast of the State of Rio de Janeiro.

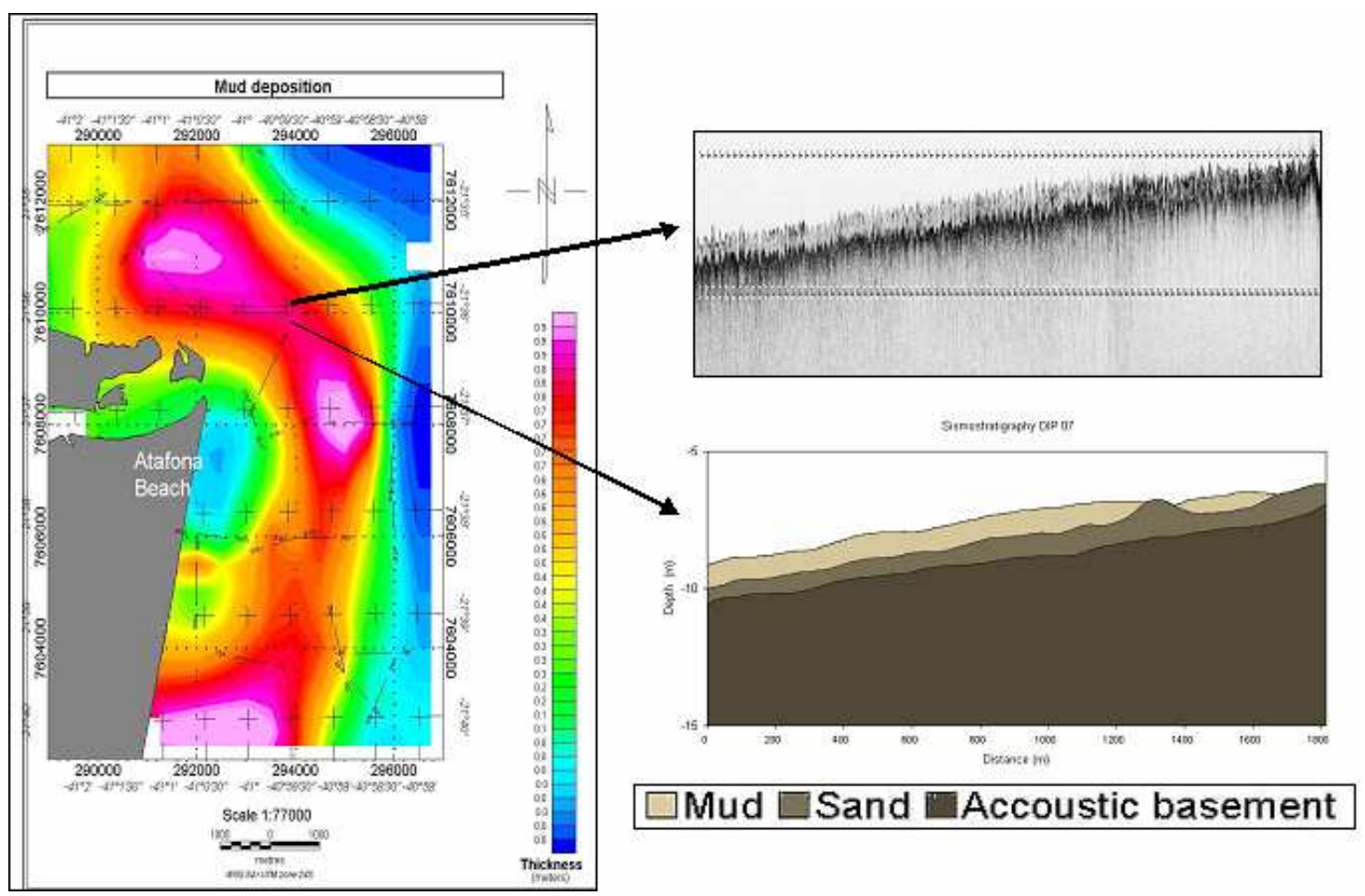

Fig. 2. Map of the location of the geophysical profiles showing the mud thickness (left) around the Paraíba do Sul outlet. At right (top) are the seismic data showing the contrast between the mud (light gray) and sand (dark gray). The sismo-stratigraphic interpretation is given below. 


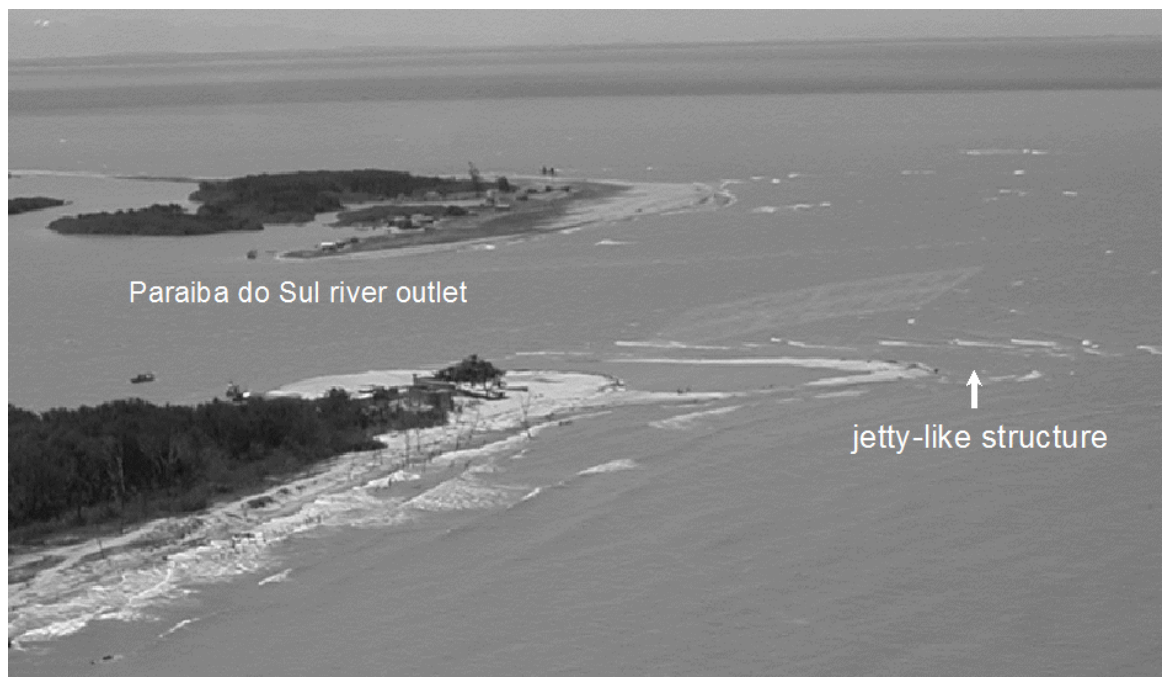

Fig. 3. A partially buried jetty forming a barrier to the passage of river sediments.

\section{ACKNOWLEDGEMENTS}

We wish to express our thanks to Dr. Susana Vinzon from the Programa de Engenharia Naval e Oceânica - COPPE/UFRJ for her help in providing the facilities for the field work.

\section{REFERENCES}

ARGENTO, M. S. F. The Paraíba do Sul retrogradation and the Atafona environmental impact. In: CLAUDIO NEVES (Ed.). Coastline of Brazil. ASCE, 1989. p. $267-$ 277.

BASTOS, A. C.; SILVA, C. G. Caracterização morfodinâmica do litoral Norte Fluminense, RJ, Brasil. Rev.Bras. Oceanogr., v. 48, n. 1, p. 41-60, 2000.

CASSAR, J. C. M.; NEVES, C. F. Aplicação das rosas de transporte litorâneo à costa fluminense. RBE: Caderno de Recursos Hídricos, v. 11, n. 1, p. 81-106, 1993.

COSTA, G.; NEVES, C. F. O estuário do rio Paraíba do Sul. In: SIMPÓSIO BRASILEIRO DE RECURSOS HÍDRICOS, 10.; SIMPÓSIO DE RECURSOS HÍDRICOS DO CONE SUL, 1., 1993, Gramado, Rio Grande do Sul. v. 2, p. 31-40, 1993.

COSTA, G.; NEVES, C. F. Influência das obras hidráulicas no rio Paraíba do Sul sobre o seu estuário. In: SIMPÓSIO BRASILEIRO DE RECURSOS HÍDRICOS, 11: SIMPÓSIO DE HIDRÁULICA E RECURSOS HÍDRICOS DOS PAÍSES DE LÍNGUA OFICIAL PORTUGUESA, 2.,1995, Recife. v. 4, p. 393-398, 1995.

DIAS, G. T. M.; SILVA, C. G.; MALSCHITZKY, I. H.; PIRMEZ, C. A frente deltaica do rio Paraíba do Sul fisiografia submarina e distribuição sedimentar. In: CONGRESSO BRASILEIRO DE GEOLOGIA, 33., Rio de Janeiro. Anais ... p. 1565-1576, 1984.

FERNANDEZ, G. B.; ROCHA, T. G.; PEREIRA, T. G.; FIGUEREDO JR, A. G. Morfologia e dinâmica de praia entre Atafona e Grussaí, litoral Norte do Estado do Rio de Janeiro. In: SIMPÓSIO NACIONAL DE GEOMORFOLOGIA, 6.; REGIONAL CONFERENCE ON GEOMORPHOLOGY, Goiânia, Goiás, 2006.

MARTIN, L.; FLEXOR, J.-M. Porque a planície costeira do Rio Paraíba do Sul não pode ser denominada de "clássico delta denominado por ondas". In: SIMPÓSIO DE GEOLOGIA REGIONAL RJ-ES, 1987. Anais... p. 7084, 1987.

MARTIN, L.; SUGUIO, K.; FLEXOR, J.-M.; TESSLER, M. G.; EICHLER, B. B. Significado geológico das variações dos graus de arredondamento das areias holocênicas da planície costeira do rio Paraíba do Sul. In: CONGRESSO BRASILEIRO DE GEOLOGIA, 33, Rio de Janeiro, 1984. Anais... SBG, v.1 , p. 119-132, 1984.

MUEHE, D. O trapeamento de areias por recobrimento de lamas como mecanismo de rompimento do balanço sedimentar. Workshop 10, Balanço de sedimentos litorâneos e aplicações em gerenciamento de processos erosivos. CONGRESSO BRASILEIRO DE OCEANOGRAFIA, 1., Itajaí, Santa Catarina, 2004. Workshop 10.

PEREIRA, F.; SPERLE, M.; MUEHE, D.; VINZON, S.; RECH, M.; SOUZA, S. R. Aplicação da sísmica rasa de alta resolução na localização de lamas na foz do Rio Paraíba do Sul, São João da Barra, RJ. In: SIMPÓSIO BRASILEIRO DE OCEANOGRAFIA, 3. 2006, São Paulo. Anais... São Paulo: EDUSP, 2006.

RIBEIRO, G. P.; ROCHA, C. H. de O.; FIGUEIREDO JR., A. G.; SILVA, C. G. SILVA, S. H. F. da; MOREIRA, P. S. da C.; GUIMARÃES, M. de S. D.; PEREIRA, A. P.; ALMEIDA, A. G. de; PINNA, B. G.; SOUZA, C. F. de; SILVA, C.; SANTOS, R. A. dos; VASCONCELOS, S. C. de. Análise espaço-temporal no suporte à avaliação do processo de erosão costeira em Atafona, São João da Barra (RJ). Rev. Bras. Cartogr., v. 56 n. 2, p.129-138, 2004

(Manuscript received 06 July 2009; revised 26 January 2010; accepted 26 April 2010) 